\title{
KEDUDUKAN JANDA DALAM HUKUM WARIS ADAT PADA MASYARAKAT PARENTAL
}

\author{
Eka Susylawati \\ (D osen Tetap Jurusan Syari'ah STA IN Pamekasan dan peserta Program D oktor \\ Ilmu Hukum U ntag Surabaya, email: adek.aldy@yahoo.co.id)
}

\begin{abstract}
A bstract:
The field of succession law in Indonesia up to now prevails law pluralism in which Islamic succession, custom succession and western succession law (Burgerlijk Wetboek) exist in society. Among those succession laws, the custom succession one is the most dominant law in society. The custom law that has dynamic characteristics also influences to the status of widow to the legacy oh her late husband, that from time to time it changes. In parental society, in the early (before RI freedom), a widow was not a heir, then the next development, the widow inherit the legacy of her late husband although the change has not received well. The cause of the change is the awareness of society in respecting the status of the widow and also because the most Indonesian society are Islam that develops the custom succession law influenced by Islamic law.
\end{abstract}

\section{Keywords:}

Waris adat, hukum waris, janda, dan parental

\section{Pendahuluan}

Adat merupakan pencerminan dari kepribadian suatu bangsa dan merupakan penjelmaan dari jiwa bangsa tersebut dari masa ke masa. Oleh karena itu setiap bangsa di dunia memiliki adat atau kebiasaan yang berbeda satu dengan lainnya. ${ }^{1}$ Demikian juga dengan bangsa Indonesia, yang di dalam wilayahnya memiliki banyak suku dan budaya yang berbeda-beda, sehingga adatnya juga berbeda.

Adat adalah endapan (renapan) kesusilaan dalam masyarakat, yang kebenarannya telah mendapat pengakuan umum suatu

1 Surojo Wignjodipuro, Pengantar dan A sas-A sas H ukum A dat (Jakarta: Gunung Agung, 1982) hlm. 1. 
E ka Susylaw ati

masyarakat. Dan suatu adat, jika memenuhi persyaratan tertentu, akan menjadi suatu hukum adat. Ada perbedaan antara adat istiadat dan hukum adat. Menurut Van vollen Hoven hanyalah adat yang mempunyai sanksi yang dapat dikategorikan sebagai hukum adat. Sanksi tersebut berupa reaksi dari masyarakat hukum yang bersangkutan.2 Sedangkan Ter Haar dengan teori keputusannya mengkategorikan adat sebagai hukum adat apabila penguasa masyarakat hukum telah menjatuhkan sanksi kepada pelanggar peraturan hukum adat. ${ }^{3}$

Hukum adat merupakan hukum non statutoir, yang sebagian besar adalah hukum kebiasaan. Hukum adat berakar pada kebudayaan tradisional dan merupakan hukum yang merupakan penjelmaan dan perasaan hukum yang nyata dari masyarakat. ${ }^{4}$

Hukum adat merupakan salah satu sumber penting untuk memperoleh bahan-bahan bagi pembangunan hukum nasional yang menuju kearah unifikasi hukum yang terutama akan dilaksanakan melalui pembuatan peraturan perundang-undangan.

Unsur-unsur kejiwaan hukum adat yang berintikan kepribadian bangsa Indonesia perlu dimasukkan ke dalam lembagalembaga hukum baru, agar hukum yang baru nanti sesuai dengan rasa keadilan dan kesadaran hukum masyarakat Indonesia.

Namun dalam perkembangannya saat ini hukum adat bagai pepatah "hidup segan mati tidak mau", hal ini disebabkan sudah banyak bidang hukum adat yang sudah tidak eksis lagi atau sudah digantikan oleh hukum yang tertulis. Dan bidang hukum adat yang tetap eksis tersebut adalah hukum waris. Salah satu pembahasan yang menarik adalah kedudukan janda atas harta peninggalan almarhum suaminya pada masyarakat parental. Dan dengan berjalannya waktu ternyata kedudukan janda tersebut dari masa ke masa mengalami perubahan, dari yang semula tidak termasuk ahli

\footnotetext{
2 Ibid. hlm. 17.

3 lbid.

4 Hukum adat mempunyai sifat antara lain: tidak tertulis, artinya tidak tertulis dalam perundang-undangan, dinamis artinya dapat mengikuti perkembangan jaman, dan hal ini nampak bahwa hukum adat pada masa lampau, berbeda isinya: hukum adat menunjukan perkembangan dan bersifat tradisional artinya bahwa hukum adat sangatlah dipengaruhi tradisi dan kebiasaan masyarakat setempat.
} 
waris, namun pada perkembangannya janda sudah mewaris. Dan salah satu perubahan kedudukan tersebut karena adanya pengaruh hukum waris Islâm terhadap hukum waris adat.

\section{Kedudukan H ukum Waris A dat dalam Tata H ukum Nasional}

Hukum waris merupakan salah satu bagian dari hukum perdata5 secara keseluruhan dan merupakan bagian terkecil dari hukum kekeluargaan. Hukum waris sangat erat hubungannya dengan ruang lingkup kehidupan manusia sebab setiap manusia pasti akan mengalami kematian. Dengan terjadinya kematian maka akibat hukum, yaitu peristiwa hukum kematian seseorang, yaitu bagaimana menyelesaikan pengurusan dan kelanjutan hak-hak dan kewajibankewajiban seseorang yang meninggal dunia. Penyelesaian hak-hak dan kewajiban-kewajiban sebagai akibat meninggalnya seseorang, termasuk dalam ruang lingkup hukum waris. ${ }^{6}$

Penggunaan istilah hukum waris maupun pengertiannya sangatlah beragam. Istilah-istilah yang dipergunakan oleh para ahli hukum maupun dalam kepustakaan ilmu hukum misalnya "hukum warisan", "hukum kewarisan ataupun istilah "hukum waris". Di antara ketiga istilah tersebut yang paling populer dan sering dipergunakan adalah istilah "hukum waris".

Demikian juga dalam memberikan pengertian tentang hukum waris. Perbedaan pengertian tersebut tidak dapat lepas dari kondisi hukum waris di Indonesia, yang masih belum unifikasi hukum sehingga hingga saat ini pengaturan masalah waris masih belum terdapat keseragaman, karena hukum waris Islâm, hukum waris Barat dan hukum waris adat berlaku dan dianut oleh masyarakat.

\footnotetext{
5 Sebagaimana hukum yang lain, hukum adat juga mengenal pembidangan hukum yang meliputi hukum negara adat, hukum tata usaha negara adat, hukum pidana adat, hukum perdata adat dan hukum antar bangsa adat. Namun semua bidang tersebut hanya bidang hukum perdata-lah yang sampai saat ini tetap eksis di Indonesia, misalnya dalam hukum pewarisan, hukum perkawinan, hukum kekerabatan dan sebagainya. Sedangkan bidang yang lain sebagaimana disebutkan di atas terdesak dengan perkembangan jaman dan sudah diganti oleh hukum tertulis, sebagai konsekwensi dari sistem hukum Eropa Kontinental yang dianut oleh Indonesia.

6 Eman Suparman, Intisari H ukum W aris In donesia (Bandung: Mandar Maju, 1991) hlm. 1.
} 
E ka Susylaw ati

Pengertian hukum waris menurut ketiga sistem hukum di atas tersebut juga berbeda. Hal ini menyebabkan perbedaan yang esensial adalah dalam proses ataupun dalam menentukan ahli waris dan bagiannya.

Menurut hukum Islâm, hukum waris adalah hukum yang mengatur pengalihan harta kekayaan dari orang yang meninggal dunia kepada ahli warisnya setelah dikurangi pembayaran hutanghutang pewaris dan pembayaran-pembayaran lain yang diakibatkan oleh wafatnya si peninggal dunia, dengan mendasarkan pada alQur'ân dan Hadîst. Pengertian menurut hukum Islâm tersebut, tidak jauh berbeda jika kita bandingkan dengan pengertian hukum waris menurut hukum Barat, yaitu kumpulan peraturan yang mengatur hukum mengenai kekayaan karena wafatnya seseorang, yaitu mengenai pemindahan kekayaan yang ditinggalkan oleh si mati dan akibat dari pemindahan ini bagi orang-orang yang memperolehnya, baik dalam hubungan antara mereka dengan mereka, maupun dalam hubungan antara mereka dengan pihak ketiga.7

Pengertian Hukum waris dalam hukum adat adalah peraturan-peraturan yang mengatur proses meneruskan dan mengoperkan barang-barang harta benda dan barang-barang yang tidak berwujud benda dari suatu angkatan manusia kepada turunannya.8 Dalam hukum waris adat, proses pewarisan telah dimulai pada waktu orang tua masih hidup sehingga proses pewarisan tidak menjadi akuut setelah orang tua meninggal dunia. Meninggalnya orang tua memang merupakan peristiwa penting dalam proses pewarisan, akan tetapi tidak mempengaruhi secara radikal proses penerusan dan pengoperan harta benda dan bukan benda tersebut.9

Memberikan harta ketika pemilik (orang tua) masih hidup kepada anaknya yang sudah berumah tangga bertujuan agar harta tersebut menjadi modal untuk penghidupannya. A pabila si peninggal harta meninggal sedangkan masih ada anak-anak yang belum diberi

\footnotetext{
${ }_{7}$ A. Pitlo, Hukum Waris Menurut Kitab Undang-Undang Hukum Perdata Belanda. Terjemahan M. Isa A rief (Jakarta: Intermasa, 1979) hlm. 1. 8 Soepomo, Bab-bab T entang H u kum A dat (Bandung: Pradya Paramita, 2000) hlm. 84. 9 Ibid. hlm. 72-73.
} 
bagian harta, maka sisa harta tersebut akan diberikan pada anak yang belum mendapat bagian. ${ }^{10}$

Sebagaimana telah dinyatakan sebelumnya bahwa hukum waris yang berlaku di Indonesia masih belum merupakan unifikasi hukum, dan akibatnya hingga saat ini pengaturan masalah waris di Indonesia masih belum terdapat keseragaman.

Dalam hukum waris adat, bentuk dan sistem hukum waris sangat erat kaitannya dengan bentuk masyarakat dan sifat kekeluargaan. Sedangkan sistem kekeluargaan berpokok pangkal pada sistem menarik garis keturunan. Berkaitan dengan sistem penarikan garis keturunan yang berlaku di Indonesia, secara umum dikenal tiga macam sistem keturunan.

Ketiga sistem keturunan tersebut sangatlah dipengaruhi oleh lokasi geografis lingkungan adatnya. Sistem keturunan tersebut adalah: Pertama, sistem patrilineal. Pada sistem ini penarikan garis keturunan menarik garis keturunan ayat atau garis keturunan nenek moyangnya yang laki-laki. Di dalam sistem ini kedudukan dan pengaruh pihak laiki-laki dalam hukum waris sangat menonjol.11 Sistem ini antara lain dianut pada masyarakat Batak, Bali, Ambon dan Irian Jaya.

Kedua, sistem matrilineal. Pada dasarnya pada sistem ini adalah menarik garis keturunan dari ibu dan seterusnya ke atas mengambil garis keturunan dari nenek moyang perempuan. Di dalam sistem ini harta ayah tidak akan diwaris oleh anak-anaknya, melainkan akan diwaris oleh. Anak-anak menjadi ahli waris dari garis perempuan/ibu karena anak-anak merupakan bagian dari ibunya, sedangkan ayahnya masih merupakan bagian dari anggota keluarganya sendiri.12 Sistem keturunan ini yang paling sedikit dianut oleh masyarakat Indonesia, karena hanya berlaku di daerah Minangkabau saja.

Ketiga, sistem parental/ bilateral. Pada sistem ini penarikan garis keturunan ditarik garis dari dua arah yaitu melalui garis ayah

10 Soedharyo Soimin, H u kum 0 rang dan K eluarga (Jakarta: Sinar Grafika, 2002) hlm. 72 11 Eman Suparman, Hukum Waris Indonesia, Dalam Perspektif Islâm, Adat dan BW (Bandung: Refika A ditama, 2007) hlm. 41. 12 lbid. 
maupun garis ibu, sehingga kekeluargaan ini pada hakikatnya tidak ada perbedaan antara pihak ibu dan pihak ayah. Dibandingkan dengan sistem patrilineal dan matrilineal, sistem keturunan yang bersifat parental adalah sistem yang paling banyak dianut di wilayah Indonesia, misalnya di jawa, Madura, Riau, Aceh, seluruh Kalimantan dan sebagainya.

Memperhatikan perbedaan-perbedaan dari ketiga sistem penarikan keturunan dengan sifat-sifat kekeluargaan masyarakatnya, maka nampak bahwa dalam sistem hukum waris adatpun sangat pluralistik. Melengkapi pluralistiknya sistem hukum waris adat yang diakibatkan beraneka ragamnya masyarakat adat di Indonesia, dua sistem hukum lainnya juga cukup dominan berlakunya dalam wilayah hukum Indonesia. Sistem hukum waris yang dimaksud adalah hukum waris Islâm yang berdasar dan bersumber pada Kitab Suci al-Qur'ân dan hukum waris Barat peninggalan Hindia Belanda yang bersumber pada BW (Burgelijk W etboek).

\section{H ukum H arta Perkawinan A dat pada M asyarakat Parental.}

Perkawinan selain bertujuan memperoleh keturunan, juga bertujuan untuk hidup bersama-sama hidup dalam suatu masyarakat dalam suatu perikatan kekeluargaan. Dan guna keperluan hidup bersama-sama tersebut membutuhkan harta benda/ kekayaan, yang nantinya akan dipergunakan membiayai kehidupan mereka beserta anak-anaknya. Harta benda tersebut disebut sebagai harta perkawinan, atau benda perkawinan atau harta benda keluarga.

Dalam praktik harta perkawinan, kekayaan guna memenuhi keperluan hidup suatu keluarga wajib dibedakan dengan harta kerabat, dengan tujuan untuk menghindari perselisihan dalam keluarga.

Secara garis besar harta perkawinan pada masyarakat parental dibagi dalam dua golongan yaitu: Pertama, harta asal, harta gawan atau disebut juga harta terpisah. Harta asal adalah kekayaan yang dimiliki oleh seseorang yang diperoleh sebelum perkawinan. Yang dikategorikan sebagai harta asal meliputi harta yang diperoleh selama perkawinan namun perolehannya melalui hibah, wasiat ataupun waris. Suatu harta asal dapat berubah wujud (misalnya mobil dijual, kemudian uangnya untuk membeli menjadi sebidang tanah), maka 
perubahan wujud tersebut tidak menghilangkan harta asal tersebut, artinya sebidang tanah tersebut statusnya tetap merupakan harta asal.

Kedua, harta bersama/ gono gini. Harta bersama adalah semua harta yang diperoleh suami isteri bersama selama dalam ikatan perkawinan, dengan tidak melihat apakah harta tersebut merupakan hasil kerja suami sendiri atau isteri sendiri ataupun suami isteri samasama mempunyai andil dalam perolehan suatu harta. Hal ini nampak dari putusan Mahkamah Agung tanggal 7 September 1956 No. 51/ K/ Sip/ 1956 yang menyatakan bahwa "menurut hukum adat semua harta yang diperoleh selama berlangsungnya perkawinan, termasuk dalam gono-gini, meskipun mungkin hasil kegiatan suami sendiri". ${ }^{13}$

Dalam praktik di masyarakat tidak tertutup kemungkinan seorang isteri mempunyai harta pencaharian sendiri yang diperolehnya karena bekerja atau berusaha sendiri sebagai petani, pedagang atau karyawan lainnya. Hal ini terutama nampak pada masyarakat yang menganut sistem keturunan parental.

Pada dasarnya isteri dengan hak miliknya sendiri berhak untuk berbuat sendiri atas harta miliknya, ia bebas melakukan transaksi jual beli, pengibahan dan lain sebagainya dengan pihak lain atas harta miliknya, walaupun tanpa persetujuan atau bantuan dari suaminya.

Praktik pada masyarakat parental tersebut sangatlah berbeda jika kita bandingkan dengan sistem keturunan patrilineal yang menggolongkan seorang isteri sebagai orang yang tidak mampu melakukan perbuatan hukum sehingga isteri tersebut tidak mempunyai hak.14 Namun dalam perkembangan saat ini wanita sepatutnya diperlakukan sejajar dengan pria, apalagi jika dilihat dari peran isteri yang bertanggung jawab penuh atas kehidupan rumah tangganya sehingga ia berhak mengatur harta kekayaan rumah

13 Hilman Hadikusuma, H ukum W aris A dat (Bandung: Alumni, 1980) hlm. 70.

${ }^{14} \mathrm{Hal}$ ini berdasarkan Keputusan dari Landraad (bila dibandingkan dengan saat ini Landraad disamakan dengan Pengadilan Negeri) Pematang Siantar tanggal 11 Oktober 1938. Lihat Hilman Hadikusuma, Hukum Waris Adat (Bandung: Alumni, 1980) hlm. 73. 
tangganya, demikian juga pewarisannya, dan bukan anggota kerabat suami ataupun yang lainnya.

Pada masyarakat parental, kapan suatu harta diperoleh (asal usulnya) sangat penting menentukan pada kedudukan harta perkawinan. Asal usul harta tersebut sangatlah berkait dengan ketika perkawinan harus berakhir dengan perceraian, maka tidak jarang suami isteri akan memilah-milah mana harta yang termasuk dalam harta asal dan harta bersama. Harta asal akan merupakan hak dari yang bersangkutan, sedangkan harta bersama akan dibagi dua antara suami isteri dengan bagian masing-masing setengah.

Demikian juga jika salah satu dari suami isteri meninggal terlebih dahulu, maka harta bersama akan dibagi dua, sedangkan harta asal masih belum terdapat kesamaan pendapat, apakah suami/isteri tersebut mewaris dari pasangannya. Jika yang meninggal terlebih dahulu adalah isteri, biasanya tidak akan terlalu membuat masalah terhadap duda. Hal ini disebabkan walaupun duda tidak mewaris dari harta asal isterinya, namun pada umumnya seorang duda akan tetap dapat melangsungkan hidup secara layak. Namun jika yang meninggal terlebih dahulu adalah suami, hidup janda akan dapat terlantar, sehingga sudah selayaknyalah jika harta peninggalan almarhum suaminya tidak banyak, maka janda dapat menguasai harta tersebut selama janda hidup atau kawin lagi. A tau juga dapat mengkategorikan janda sebagai ahli waris dari almarhum suaminya.

\section{Kedudukan Janda dalam Hukum Waris Adat pada Masyarakat Parental}

Di dalam keluarga atau lebih tepat dalam suatu rumah tangga, seorang isteri jika suaminya telah meninggal dunia, mempunyai kedudukan yang istimewa. Hal ini disebabkan jika anak-anaknya telah mencar semua, isteri sebagai janda tinggal sendiri di dalam rumah tangga yang ditinggalkan oleh almarhum suaminya dan berhak tetap tinggal di rumah tangga itu dengan hak memegang harta benda yang ditinggalkan, jika janda tersebut memerlukannya dan selama memerlukan untuk kehidupannya.

Jika syarat untuk adanya waris mendasarkan pada tali kekeluargaan atau karena keturunan, maka seorang janda bukanlah 
merupakan ahli waris dari almarhum suaminya. Hal ini nampak dari hukum adat yang berlaku. Tetapi pada kenyataannya, suami isteri yang terikat dalam suatu perkawinan memiliki hubungan baik lahir ataupun batin yang sedemikian eratnya sehingga melebihi hubungan suami dengan saudara sekandungnya.

Jika kita bandingkan pada masyarakat patrilineal atau matrilineal, tidak banyak mengandung permasalahan waris, termasuk pada keluarga-keluarga yang tunduk pada hukum waris Islâm, maka dalam sistem parental yang mayoritas dianut oleh sebagian besar masyarakat di Indonesia, masalah waris menumbulkan masalah. Antara lain masalah kedudukan janda, terutama apakah janda mewarisi dari suaminya yang meninggal dunia atau hanya sebatas menguasai atau menikmati warisan. Hal ini dapat diketahui dari yurisprudensi atau hasil penelitian yang pernah dilakukan terhadap keluarga-keluarga di pulau Jawa.15

Sebagaimana telah dijelaskan sebelumnya bahwa hukum adat mempunyai sifat yang dinamis. Dan kedinamisan tersebut juga terjadi dalam kedudukan janda dalam mewaris atau tidak dari almarhum suaminya.Pada awalnya pada masyarakat parental, seorang janda bukanlah ahli waris dari almarhum suaminya. Akibatnya ketika seorang suami meninggal dunia, seringkali janda akan pulang kerumahnya sendiri, dengan tanpa membawa apapun dari harta peninggalan suaminya. Hal ini dibuktikan dengan putusan landraad Purworejo tanggal 25 Agustus 1937 yang isinya antara lain menyatakan bahwa "barang pencaharian dan barang gono-gini jatuh kepada janda dan anak angkat sednagkan barang asal kembali kepada saudara yang meninggalkan warisan, jika yang meninggal tidak mempunyai anak keturunannya sendiri".16 Dasar hukum yang melandasi hal tersebut karena secara prinsip harta asal akan kembali ke asalnya, sehingga yang lebih berhak terhadap harta peninggalan suami pada waktu itu adalah kerabat suami terutama saudarasaudara suami. Tidak mewarisnya seorang janda terhadap harta peninggalan tersebut menunjukan bahwa perlindungan terhadap kelangsungan hidup janda setelah ditinggal almarhum suaminya, dalam kenyataannya tidak ada sama sekali.

15 H ilman Hadikusuma, H ukum W aris A dat. hlm. 97.

$16 \mathrm{lbid}$. hlm. 98. 
Kedudukan hak waris janda berubah, dan hal ini dibuktikan dengan putusan Raad Van Justitie Batavia tanggal 17-26 Nopember 1939 yang isinya antara lain menyatakan bahwa "pada hakekatnya janda perempuan bukan seorang ahli waris terhadap harta warisan almarhum suaminya, akan tetapi ia berhak menerima penghasilan dari peninggalan suaminya, jika ternyata harta gono gini tidak mencukupi. ${ }^{17} \mathrm{Harta}$ peninggalan yang tidak dapat diwaris tersebut hanyalah meliputi terhadap harta asal, sedangkan dalam keadaan demikian janda masih dapat membawa sebagai harta yang diperoleh selama perkawinan. Dasar hukum yang melandasi hal tersebut karena secara prinsip Bilamana sebelumnya janda bukanlah ahli waris dari almarhum suaminya, pada perkembangan yang kedua janda lebih memiliki kedudukan yang lebih baik. Pada tahap ini posisi janda tetap bukan ahli waris dari almarhum suaminya, namun janda masih dapat menguasai harta peninggalan almarhum suaminya sampai sang janda meninggal dunia atau kawin lagi. Yang dimaksud berhak menguasai adalah bahwa janda dapat menggunakan atau menikmati harta peninggalan almarhum suaminya, sehingga hidupnya tidak terlantar. Misalnya harta peninggalan almarhum suaminya berupa sebuah rumah dan sebidang sawah, maka janda tersebut dapat menempati rumah tersebut dan menanami sawahnya serta mengambil hasil dari sawah tersebut. Yang menjadi larangan adalah janda mengalihkan harta peninggalan tersebut.

Dengan hak menguasai seorang janda di masyarakat parental, mengakibatkan harta peninggalan dapat bersifat tidak dapat dibagibagi atau pelaksanaanya ditunda untuk waktu yang cukup lama ataupun hanya sebagian yang dapat dibagi. Apabila harta peninggalan almarhum suaminya banyak, tidak masalah untuk diadakan pembagian terhadap sebagian harta, sedangkan sebagian yang lain ditahan dengan alasan masih ada janda yang membutuhkan sehingga kehidupannya tidak terlantar. Sebaliknya jika harta peninggalannya terbatas, sebagaimana contoh di atas (hanya sebuah rumah dan sebidang sawah) maka pembagian akan ditunda. Demikian juga terhadap harta bersama yang diperolehnya selama perkawinan. Hal tersebut diperkuat oleh Yurisprudensi Mahkamah Agung, melalui putusannya tanggal 24 Juni 1959 Nomor

17 lbid. 
187/ K/ Sip/ 1959, menyatakan bahwa menurut hukum adat di sekitar Mojokerto dan Jombang seorang janda yang memegang barangbarang yang merupakan gono-gini dari janda itu dan almarhum suaminya, tidak dapat diganggu gugat tentang barang-barang itu oleh ahli waris dari almarhum suami itu, selama janda tersebut masih hidup dan tidak kawin lagi.

Pada perkembangan yang ketiga, yakni setelah tahun 1960 terdapat perubahan terhadap kedudukan janda yang berkait dengan harta peninggalan almarhum suaminya. Bilamana pada perkembangan yang pertama tidak mewaris dan pada perkembangan yang kedua mempunyai hak untuk "menguasai" maka pada pekembangan ketiga, seorang janda adalah ahli waris dari almarhum suaminya. Dan yang dimaksud dengan mewaris tersebut adalah mewarisi harta asal suaminya. Hal ini sesuai dengan Yurisprudensi Mahkamah Agung tanggal 20 April 1960 No. 110K/ Sip/ 1960 yang menyatakan bahwa menurut hukum adat, seorang janda adalah juga menjadi ahli waris dari almarhum suaminya. Dengan putusan Mahkamah Agung tersebut berarti mengubah salah satu prinsip atau asas dalam hukum harta perkawinan, yang menyatakan bahwa harta asal akan kembali ke asal, sehingga dengan asas tersebut pada awalnya seorang janda bukanlah ahli waris dari harta asal almarhum suaminya, karena tidak termasuk dalam orang yang memiliki darah.

Putusan tersebut diperkuat dengan Putusan Mahkamah Agung tanggal 14 Juni 1968 No. 100K/ Sip/ 1967, yang memberikan hak waris dari bagian harta bersama kepada janda. Putusan tersebut menyatakan bahwa mengingat pertumbuhan masyarakat menuju ke arah persamaan kedudukan antara pria dan wanita dan pengakuan janda sebagai ahli waris, Mahkamah Agung membenarkan pertimbangan dan putusan pengadilan Tinggi yang menetapkan bahwa dalam hal meninggalnya seorang suami dengan meninggalkan seorang janda, seorang anak laki-laki dan seorang anak perempuan, janda berhak atas separuh dari harta bersama, sedang sisanya dibagi antara janda dan kedua anaknya masing-masing mendapat sepertiga bagian.

Dari isi putusan tersebut nampak bahwa janda, selain memperoleh setengah dari harta bersama perkawinan, juga memperoleh bagian warisan dari harta bersama almarhum suaminya. 
E ka Susylawati

Malahan menurut hukum adapt di Jawa, apabila dalam perkawinan tidak ada anak, maka harta gono-gini akan beralih seluruhnya kepada janda. ${ }^{18}$ Dengan demikian janda terhadap harta bersama memperoleh dari dua sumber yaitu dari hak bagiannya sendiri dan hak waris dari harta bersama suaminya.

Pertanyaan yang dapat timbul adalah apabila suami isteri tersebut tidak mempunyai anak. A pabila ada anak, maka segala harta benda kelak akan dialihkan kepada anak, karena anak itu wajib memelihara ibunya dengan sebaik-bakinya.

Dalam kehidupan masyarakat parental banyak contoh yang dapat dijadikan acuan dalam pembagian dan pemakaian harta peninggalan. Misalnya jika ada janda dan anak-anak yang telah dewasa (mentas) maka alternatifnya antara lain: (1) Harta peninggalan (harta asal suami, harta asal isteri dan harta bersama dibagi diantara semua anak. Dan janda (ibu) akan tinggal dengan salah satu anaknya dan dipelihara oleh semua anak atau oleh anak yang ditumpanginya. Janda tidak mendapat bagian sedikitpun dan tidak menuntut untuk mendapat bagian karena kehidupannya telah terjamin; (2) atau janda mendapat sebagian dari harta peninggalan misalnya sebuah rumah dan sebidang sawah, dan barang-barang peninggalan yang lain dibagi antara anak-anak.

\section{Pengaruh Hukum Waris Islâm terhadap Hak Waris Janda dalam M asyarakat Parental}

Allâh telah menetapkan aturan main bagi kehidupan manusia di atas dunia dan aturan ini berisi tentang perbuatan yang boleh dan tidak boleh dilakukan oleh manusia. Aturan Allâh tentang tingkah laku manusia secara sederhana adalah syariah atau hukum syara' yang lazim disebut hukum Islâm. ${ }^{19}$

Segi kehidupan manusia diatur oleh Allâh dapat dikelompokkan kepada dua kelompok, yaitu pertama, hal-hal yang berkaitan dengan hubungan lahir manusia dengan Allâh penciptanya.

18 Wirjono Prodjodikoro, Hukum Warisan di Indonesia (Bandung: Sumur Bandung, 1980) hlm. 22.

19 Moh. Muhibbin dan Abdul Wahid, Hukum Kewarisan Islâm, Sebagai Pembaharuan H ukum Positif di Indonesia (Jakarta: Sinar Grafika, 2009) hlm. 1. 
Aturan tersebut disebut sebagai hukum ibadah. Yang kedua, adalah hal-hal yang berkaitan dengan hubungan antara manusia satu dengan manusia lainnya dan alam sekitarnya. A turan tersebut disebut hukum muamalat. 20

Di antara aturan yang mengatur hubungan sesama manusia yang ditetapkan Allâh adalah aturan tentang harta warisan, yaitu harta dan pemilikan yang timbul sebagai akibat dari suatu kematian. Harta yang ditinggalkan oleh seseorang yang meninggal dunia memerlukan pengaturan tentang siapa yang berhak menerimanya, berapa jumlahnya dan bagaimana cara mendapatkannya.

Hukum waris Islâm merupakan aturan yang bersifat normatif, yang idealnya menjadi pedoman bagi ummat beragama Islâm. Dan seyogyanya dalam penerapan hukum waris Islâm tidak hanya menggunakannya ketika ada sengketa waris, tetapi juga secara sadar menerapkannya ketika secara sukarela. Ironisnya walaupun sebagian besar masyarakat Indonesia beragama Islâm, namun belum banyak orang Islâm yang memiliki pengetahuan tentang hukum waris Islâm.

Ditinjau dari perspektif sejarah, penerapan hukum waris Islâm pada jaman penjajahan Belanda tidak dapat berkembang secara baik, dan secara politis posisinya dikalahkan oleh sistem hukum waris adat. Pada saat itu diintrodusir teori resepsi21 yang bertujuan untuk mengangkat hukum waris adat dan menyisihkan penggunaan hukum waris Islâm.

Sebagian para sarjana hukum menganggap hukum waris Islâm tidak mempunyai sistem dan hanya bersandar pada asas patrilineal. Sementara itu, di kalangan umat Islâm sendiri banyak

\footnotetext{
20 lbid. hlm. 2.

21 Teori receptie diajukan oleh Christian Snouck Hurgronje (1857-1936), yang kemudian dikembangkan oleh Van Vollenhoven dan Ter Haar, yang menyatakan bahwa bagi rakyat pribumi pada dasarnya berlaku hukum adat. Hukum Islâm berlaku kalau norma hukum Islâm telah diterima oleh masyarakat sebagai hukum adat. Teori receptie ini berpangkal dari keinginan pemerintah penjajah Belanda yang menginginkan agar orang pribumi jangan sampai kuat memegang ajaran Islâm, sebab pada umumnya orang-orang yang taat pada ajaran Islâm dan hukum Islâm, tidak mudah dipengaruhi oleh peradaban Barat. Lihat Afdol, Pengembangan Teori Implementasi H ukum W aris Islâm di Indonesia, Disampaikan pada pengukuhan Jabatan Guru Besar di Fakultas Hukum Universitas A irlangga, Surabaya, tanggal 23 Pebruari 2008.
} 
E ka Susylaw ati

pula yang mengira tidak ada sistem tertentu dalam hukum waris Islâm, sehingga menimbulkan sebuah anggapan seolah-olah hukum waris Islâm merupakan hukum yang rumit dan sulit.

Wujud warisan atau harta peninggalan menurut hukum Islâm sangat berbeda dengan wujud warisan menurut hukum waris Barat maupun hukum waris adat. Warisan menurut hukum Islâm adalah sejumlah harta benda serta segala hak dari yang meninggal dunia dalam keadaan bersih. Artinya harta peninggalan yang diwaris oleh ahli waris adalah benda dan segala hak, setelah dikurangi dengan pembayaran hutang-hutang pewaris dan pembayaran-pembayaran lain yang diakibatkan oleh wafatnya orang yang meninggal dunia.

Sebagai bagian dari hukum perdata dimana dalam salah prinsipnya mengenal pilihan hukum, maka pada dasarnya masyarakat yang memeluk agama Islâm tidak harus tunduk kepada hukum waris Islâm. Hukum waris Islâm berlaku secara sempurna bagi warga Negara Indonesia keturunan Arab, karena bagi mereka pada umumnya berlaku hukum waris adat asal mereka yaitu hukum waris Islâm.22

Dalam hukum waris Islâm seseorang dapat mewaris dari harta seseorang karena sebab perkawinan.23 Dan hubungan kewarisan baru dapat terjadi jika perkawinan yang dilakukan tersebut sah. Jika seorang suami meninggal dunia, maka isterinya atau jandanya mewarisi harta suaminya. Demikian juga jika seorang isteri meninggal dunia, maka suaminya mewarisi harta isterinya.

Dengan demikian seorang isteri merupakan ahli waris dari almarhum suaminya, dengan syarat ketika pewarisan tersebut dilakukan, perkawinan mereka harus utuh ketika suaminya

22 Moh. Muhibbin dan Abdul Wahid, Hukum Kewarisan Islâm, Sebagai Pembaharuan H ukum Positif di Indonesia hlm. 43.

23 Menurut hukum kewarisan Islâm ada tiga sebab mewaris, yaitu karena hubungan kekeluargaan (adanya hubungan darah atau famili, karena perkawinan dan karena wala' (suatu hubungan yang ditetapkan oleh hukum Islâm karena tuannya telah memberikan kenikmatan untuk hidup merdeka dan mengembalikan hak asasi kemanusiaan kepada budaknya). Pada masa sekarang mewaris karena wala' sudah kehilangan maknanya karena secara umum perbudakan sudah tidak ada lagi. Lihat A. Rachmad Budiono, Pembaharuan Hukum kewarisan Islâm di Indonesia (Bandung: Citra Aditya Bakti, 1999) hlm. 8-9. 
meninggal dunia. Apabila perkawinan mereka sudah putus, maka tidak lahir hubungan perkawinan. Bagian warisan janda diatur dalam al-Qur,ân surat al-Nisâ' ayat 12 yaitu: (1) Apabila pewaris tidak mempunyai anak, maka bagian waris janda adalah seperempat; (2) dan apabila pewaris mempunyai anak, maka bagian warisan janda adalah seperdelapan.

A pabila pewaris meninggalkan dua atau tiga atau empat janda maka mereka berbagi bagian warisan yang ada. Misalnya seorang suami meninggal dunia meninggalkan seorang anak laki-laki dan dua orang janda, maka bagian warisan mereka adalah: dua orang janda memperoleh 1/ 8 sehingga masing-masing janda memperoleh 1/ 16 dan seorang anak laki-laki memperoleh $7 / 8$ bagian.

Sebagaimana telah dijelaskan sebelumnya bahwa dalam hukum waris adat, seorang janda bukan ahli waris dari almarhum suaminya, dan pada perkembangan terakhir seorang janda sudah merupakan ahli waris. Pertanyaan yang kemudian timbul adalah kalau memang mewaris, berapakah bagian yang akan diterima seorang janda? Ternyata pertanyaan ini tidak mudah dijawab, karena selain di masyarakat parental masih ada yang berpendapat bahwa seorang janda hanya mempunyai hak untuk "menikmati/ menguasai", juga masih tidak ada keseragaman dalam menentukan berapa besarnya bagian janda. Sebagian berpendapat bahwa janda memperoleh bagian yang sama besarnya dengan anak, sehingga ketika seorang suami meninggalkan seorang janda dan dua anak, maka janda akan memperoleh 1/ 3 bagian.

Pendapat yang lain menyatakan bahwa bagian janda adalah 1/ 8 jika ada anak dan 1/4 bagian apabila dalam perkawinan tidak ada anak. Dan jika kita bandingkan bagian janda tersebut dengan hukum waris Islâm, maka hal tersebut merupakan bentuk pengaruh hukum waris Islâm terhadap perkembangan hukum waris adat.24

24 Faktor-faktor yang mempengaruhi perkembangan hukum adat, disamping kondisi alam dan watak masyarakat yang bersangkutan, juga dipengaruhi oleh magi dan animisme, agama, kekuasaan-kekuasaan yang lebih tinggi dari persekutuan hukum adat dan hubungan dengan orang-orang ataupun kekuasaan asing. Lihat Surojo Wignjodipuro, P engantar dan A sas-A sas H u kum A dat hlm. 31. Faktor agama sangatlah mempengaruhi hukum adat, terutama sekali agama Islâm dalam bidang perkawinan dan lembaga wakaf. Orang yang memeluk agama Islâm tunduk pada hukum 
Upaya untuk mendekatkan orang Islâm dengan kel slâmannya terus-menerus dilakukan. Salah satu upayanya adalah mendekatkan orang Islâm dengan hukum Islâm. Dan bidang hukum Islâm yang telah lama diupayakan adalah bidang hukum kewarisan. 25 Upaya yang monumental adalah dengan disahkannya Kompilasi Hukum Islâm berdasarkan Instruksi Presiden Nomor 1 Tahun 1991, yang merupakan legislasi hukum waris Islâm ke lingkungan hukum positif di Indonesia. Instruksi Presiden tersebut juga diperkuat dengan adanya Undang-Undang Nomor 7 Tahun 1989 tentang Peradilan Agama, yang salah satu kewenangannya adalah memeriksa perkara waris antar orang yang beragama Islâm dan memutus dengan mendasarkan pada hukum waris Islâm.

N amun sebagai konsekwensi dari hukum perdata, orang Islâm yang akan membagi warisan tidak harus tunduk pada ketentuan hukum waris Islâm. Artinya orang Islâm boleh menggunakan pranata hukum yang lain (hukum waris adat atau Barat) apabila hendak membagi warisan. Bisa disimpanginya hukum waris Islâm tersebut dengan syarat tidak ada perselisihan dan menjadi perkara di pengadilan. Namun apabila menjadi perkara, menurut Penjelasan Umum Undang-Undang Nomor 3 Tahun 2006 tentang Perubahan Atas Undang-Undang Nomor 7 Tahun 1989, maka selama subyek hukum yang berperkara beragama Islâm, maka akan menjadi kewenangan pengadilan agama dan pengadilan agama akan dalam memeriksa dan memutus akan menerapkan hukum waris Islâm.

Dengan tidak diperkenankannya pilihan hukum dalam perkara waris antar orang yang beragama Islâm, maka lambat laun hukum waris Islâm akan dikenal dan mengakar pada masyarakat, dan seorang janda akan selalu mewaris dari harta peninggalan almarhum suaminya.

perkawinan Islâm. Bahkan dapat dikatakan bahwa hukum perkawinan Islâm sudah menjadi hukum perkawinannya sendiri (telah terjadi resepsi hukum).

25 Moh. Muhibbin dan Abdul Wahid, Hukum Kewarisan Islâm, Sebagai Pembaharuan H ukum Positif di Indonesia hlm. 173. 
Kedudukan J anda

\section{Penutup}

Hukum waris adat masih sangat mengakar dan diterapkan di masyarakat, termasuk masyarakat yang beragama Islâm, sehingga perlu dikaji secara mendalam mengenai faktor-faktor persesuaian dan perbedaan hukum waris adat dan hukum waris Islâm, yang kemudian dilakukan dalam hukum kodifikasi hukum waris nasional yang didambakan oleh masyarakat muslim Indonesia. Pengkajian penting dilakukan terutama dalam menentukan kedudukan hak waris janda, karena walaupun menurut hukum waris adat masyarakat parental, janda merupakan ahli waris dari almarhum suaminya, namun belum ada kesamaan tentang berapa bagiannya.

\section{D aftar Pustaka}

Afdol, Pengembangan Teori Implementasi Hukum Waris Islâm di Indonesia, Disampaikan pada pengukuhan Jabatan Guru Besar di Fakultas Hukum universitas Airlangga Surabaya tanggal 23 Pebruari 2008.

Budiono, A. Rachmad. Pembaharuan Hukum kewarisan Islâm di Indonesia. Bandung: Citra A ditya Bakti, 1999.

Hadikusuma, Hilman. H ukum W aris A dat. Bandung: Alumni, 1980.

Muhibbin, Moh. dan Wahid, Abdul. Hukum Kewarisan Islâm, Sebagai Pembaharuan H ukum Positif di Indonesia. Jakarta: Sinar Grafika, 2009.

Pitlo, A. Hukum Waris M enurut Kitab Undang-U ndang Hukum Perdata Belanda. Terjemahan M. Isa A rief. Jakarta: Intermasa, 1979.

Prodjodikoro, Wirjono. Hukum Warisan di Indonesia. Bandung: Sumur Bandung, 1980.

Soepomo, Bab-bab Tentang Hukum Adat. Bandung: Pradya Paramita, 2000.

Soimin, Soedharyo,H ukum O rang dan K eluarga. Jakarta: Sinar Grafika, 2002. 
E ka Susylawati

Suparman, Eman. Hukum W aris Indonesia, D alam Perspektif Islâm, A dat dan BW. Bandung: Refika Aditama, 2007.

------. Intisari H ukum W aris Indonesia. Bandung: Mandar Maju, 1991.

Wignjodipuro, Surojo. Pengantar dan A sas-A sas Hukum A dat. Jakarta: Gunung Agung, 1982. 